[13] Fedorova, D. V. (2016). New salty waffle products "Fish Krekis" with fish \& plant semifinished products. TRAEKTORIÂ NAUKI, 4 (9). 3.6-3.17. Available at: http://pathofscience.org/index.php/ps/article/ view/113

[14] Knorr, D. (1977). Potato protein as partial replacement of wheat flour in bread. Journal of Food Science, 42 (6), 1425-1427. doi: https://doi.org/10.1111/j.1365-2621.1977.tb08390.x

[15] Sidhu, J. S., Kabir, Y., Huffman, F. G. (2007). Functional Foods from Cereal Grains. International Journal of Food Properties, 10 (2), 231-244. doi: https://doi.org/10.1080/10942910601045289

[16] Marchetti, L., Califano, A. N., Andrés, S. C. (2018). Partial replacement of wheat flour by pecan nut expeller meal on bakery products. Effect on muffins quality. LWT, 95, 85-91. doi: https://doi.org/10.1016/ j.lwt.2018.04.050

[17] Yasin, N. M. N., Shalaby, S. M. (2013). Physiochemical and sensory properties of functional low fat cheesecake manufactured using cottage cheese. Annals of Agricultural Sciences, 58 (1), 61-67. doi: https://doi.org/10.1016/j.aoas.2013.01.009

[18] Secchi, N., Fadda, C., Sanna, M., Conte, P., Del Caro, A., Catzeddu, P., Piga, A. (2017). Effectiveness of modified atmosphere packaging and ovine whey powder in extending the shelf life of whey cheesecakes. LWT, 75, 373-378. doi: https://doi.org/10.1016/j.lwt.2016.09.018

[19] Abdel-Salam, A. M., Ahmed, S. M. (2007). Preparation and evaluation of formulated functional cheesecake for diabetics. Journal of Food, Agriculture \& Environment, 5 (3-4), 8-11.

\title{
DEVELOPMENT OF NEW CRISPY BREADS WITH THE INCLUSION OF VEGETABLE ADDITIVES AND EVALUATION OF THEIR QUALITY
}

\author{
Maryna Mardar \\ Vice-Rector for Scientific and Pedagogical Work and International Relation \\ Odessa National Academy of Food Technologies \\ 112 Kanatna str., Odessa, Ukraine, 65039 \\ marinamardar2003@gmail.com \\ Tetiana Bordun \\ Department of technology of mixed feed and biofuel \\ Odessa National Academy of Food Technologies \\ 112 Kanatna str., Odessa, Ukraine, 65039 \\ bordun.tatjana@gmail.com \\ Rafaela Znachek \\ Department of Marketing, Business and Trade \\ Odessa National Academy of Food Technologies \\ 112 Kanatna str., Odessa, Ukraine, 65039 \\ rafaehlab@yandex.ru \\ Svitlana Vikul \\ Department of Food chemistry and expertise \\ Odessa National Academy of Food Technologies \\ 112 Kanatna str., Odessa, Ukraine, 65039 \\ vizaj_vik@ukr.net
}

Abstract

Spelt-based crispy breads with the inclusion of herbal supplements (powders of milk thistle, mountain ash, wild rose and green tea extract) and the results of assessing the quality of new products by organoleptic and physico-chemical indicators are 
presented. For a tasting evaluation, a point scale has been developed for the organoleptic evaluation of sugary-grain crispy breads. On the basis of which the organoleptic analysis of crispy breads, enriched with herbal supplements, has been carried out It is established that the introduction of vegetable additives in the composition of crispy bread leads to an improvement in the organoleptic characteristics of finished products. These products are characterized by a crispy, porous structure, an attractive light cream color, a harmonious taste, a pronounced smell of used additives. According to the results of the tasting evaluation, samples enriched with herbal supplements received the highest score in relation to the control sample, which meets the requirements of potential consumers. On the basis of physico-chemical indicators, it has been established that the introduction of grain additives to crispy breads does not impair the physic-chemical properties of these products.

On the basis of the obtained data, the expediency of the production of new spelt-based crispy breads with the inclusion of enriching additives with improved organoleptic properties is substantiated.

Keywords: crispy breads, point scale, tasting of crispy breads, quality evaluation.

\section{Introduction}

The quality of a food product largely depends not only on its nutritional value, but also on its organoleptic and physico-chemical properties, which largely determine its purchasing attractiveness and allow to determine how this product is perceived by the consumer $[1,2]$.

To assess the consumer preferences of food products, organoleptic methods are widely used, based on the analysis of sensations of the human sense organs [1-3]. This is due to the fact that the organoleptic characteristics of products, such as appearance, taste, smell, color and structure are of paramount importance for the consumer, as quickly, without any physicochemical studies, gives a general idea of the product quality. It is these indicators that have the psychological impact on the consumer, as a result of which he leaves his choice on this product [3,4]. This is also confirmed by marketing research [5] of which it is clearly seen that the consumer, when choosing a food product, is guided primarily by taste and aromatics. In this connection, when developing new products, special attention should be paid to organoleptic indicators.

Nowadays, ready-to-eat products - crispy breads that have good consumer properties and a long shelf life - are of particular interest among consumers [5]. Research is being conducted to develop new health-improving crispy breads. Thus, researchers have developed crispy breads based on wheat bran, rye and wheat flour, which are characterized by increased nutritional and biological value [6]. Crispy breads based on buckwheat flour and grape seed powder make it possible to get gluten-free crispy breads. On the basis of the research conducted by scientists, it has been established that breads have high quality indicators and can be recommended both in dietary food and for consumption by wide strata of the population [7]. Ukrainian scientists have developed bread cakes made from a mixture of wheat and rye flour with natural fortifier, flavor flavors (amaranth seed flour, natural spices, $\mathrm{CO}_{2}$, extracts of aromatic raw materials). Crispy products have been recommended by scientists for feeding diabetic patients [8]. Although they are being conducted in this direction, the range of crispy breads on the Ukrainian market is minimal and does not always meet the requirements of consumers [5], and therefore needs to be expanded and optimized. Also, insufficient attention is paid to the use of spelled as a valuable raw material in the production of new grain products, namely, crispy bread.

In this regard, the purpose of the research is development and assessing the quality of new crispy breads of increased nutritional and biological value based on spelled with the inclusion of natural additives of plant origin, will contribute to expanding the range of health food products with desired consumer properties.

\section{Materials and methods}

To carry out the experiment, new spelt-based crispy breads with the inclusion of herbal supplements, which were added separately (fruit powders of milk thistle, mountain ash, rosehip, green tea extract), were used as objects of research. According to the previously calculated recipe [9], all the initial components of the crispy bread were subjected to sieving, magnetic cleaning and dosage. The resulting mixture was sent to a special apparatus for the production of whole-grain 
expanded grains of the $\mathrm{YBX}-80 \times 8$ brand (Ukraine), where its thermal and mechanical processing took place at the modes recommended for this equipment: duration $8 \mathrm{~s}, \mathrm{P}=2.5 \ldots 5 \mathrm{MPa}$. As a result, crispy breads were received in the form of round briquettes: control - spelt-based crispy breads; sample 1 - spelt-based crispy breads with the inclusion of $5 \%$ of rosehip powder; sample 2 - speltbased crispy breads with the inclusion of $5 \%$ mountain ash powder; sample 3 - spelt-based crispy breads with the inclusion of $5 \%$ milk thistle powder; sample 4 - spelt-based crispy breads with the inclusion of $5 \%$ green tea extract powder.

The system of organoleptic evaluation of crispy breads that the food concentrates proposed in the regulatory documents of Ukraine (10) gives an incomplete and somewhat superficial characteristic of the products.

In this regard, organoleptic evaluation of new crispy breads was carried out according to the developed 5-point scale, taking into account the weighting factors of single indicators (appearance, color, structure, taste, smell) (Table 1). The development taken into account in scale and weighting coefficients carried out by an expert. The focus group consisted of experts who possessed knowledge of the authorities of grain bread and technology and technology. The significance coefficients were used in connection with the different significance of individual indicators in the general perception of an organoleptic evaluation of product quality. For the purpose of weighing factors, first of all, the main organoleptic indicators, reflecting the ability to fulfill the main purpose of the product, are highlighted. The most important for food products, in particular crispy breads, is taste, smell, structure. Of course, taste and aromatic indices in the assessment scales are allocated to $40 \ldots 60 \%$ of the total number of points, to the structure $-20 \ldots 25 \%$ points [3]. Weight coefficients in the point scale of organoleptic quality evaluation of crispy breads, which were determined by an expert, are given in Table 1.

Table 1

The point scale of organoleptic quality evaluation of properties of new crispy breads

\begin{tabular}{|c|c|c|}
\hline $\begin{array}{l}\text { Quality } \\
\text { indica- } \\
\text { tors }\end{array}$ & $\begin{array}{l}\text { Weight } \\
\text { coeffi- } \\
\text { cient }\end{array}$ & 5 \\
\hline 1 & 2 & 3 \\
\hline $\begin{array}{l}\text { appear- } \\
\text { ance }\end{array}$ & 0,15 & $\begin{array}{l}\text { The shape of the } \\
\text { products is correct, } \\
\text { the dimensions are } \\
\text { round or rectangu- } \\
\text { lar, a rough surface } \\
\text { with slight inclu- } \\
\text { sions of caps and } \\
\text { bran, with a slight } \\
\text { powderiness }\end{array}$ \\
\hline colour & 0,15 & $\begin{array}{l}\text { Uniform, matching } \\
\text { the color of the used } \\
\text { components }\end{array}$ \\
\hline $\begin{array}{l}\text { struc- } \\
\text { ture }\end{array}$ & 0,2 & $\begin{array}{l}\text { Crispy, well-devel- } \\
\text { oped porosity, with } \\
\text { no signs of cement } \\
\text { deposits }\end{array}$ \\
\hline
\end{tabular}
Characteristics of the indicator, points

\begin{tabular}{|c|c|c|c|}
\hline 4 & 3 & 2 & 1 \\
\hline 4 & 5 & 6 & 7 \\
\hline $\begin{array}{l}\text { The shape of the } \\
\text { products is correct, } \\
\text { the dimensions } \\
\text { correspond to the } \\
\text { type of products } \\
\text { with slight fractures } \\
\text { along the edges, } \\
\text { a rough surface, } \\
\text { with a piercing } \\
\text { and relief, slight } \\
\text { flouriness, presence }\end{array}$ & $\begin{array}{l}\text { Products slightly } \\
\text { deformed with } \\
\text { minor cracks and } \\
\text { fractures, a small } \\
\text { number of prod- } \\
\text { ucts has inappro- } \\
\text { priate dimensions, } \\
\text { rough surface, } \\
\text { powdery, with } \\
\text { pierce and relief, } \\
\text { the presence of }\end{array}$ & $\begin{array}{l}\text { The shape is } \\
\text { irregular, products } \\
\text { where molded, } \\
\text { non-water-bearing } \\
\text { sizes with signif- } \\
\text { icant cracks and } \\
\text { fractures, a large } \\
\text { number of pricks, } \\
\text { caps and bran, } \\
\text { swelling on almost } \\
\text { the entire surface }\end{array}$ & $\begin{array}{l}\text { The shape is irregular, } \\
\text { the products are highly } \\
\text { deformed, not propor- } \\
\text { tional to the size, has a } \\
\text { large number of cracks } \\
\text { and cracks, the pres- } \\
\text { ence of burned marks, } \\
\text { swelling on the entire } \\
\text { surface, salt }\end{array}$ \\
\hline
\end{tabular}

Fairly uniform, Not even enough, matching the color the color slightly of the used compo- does not match the nents color of the used components

Poor crispy, poorly Crispy, porous, with developed porosno signs of cement ity, the presence deposits of signs of cement deposits
Not crispy, very poorly developed porosity, signs of cement deposits
Not crispy, not developed porosity, signs of cement deposits 


\begin{tabular}{|c|c|c|c|c|c|c|}
\hline 1 & 2 & 3 & 4 & 5 & 6 & 7 \\
\hline taste & 0,3 & $\begin{array}{l}\text { Pleasant, suitable } \\
\text { for the revealed } \\
\text { taste of the addi- } \\
\text { tives used, pro- } \\
\text { nounced, without } \\
\text { foreign tastes }\end{array}$ & $\begin{array}{l}\text { Pleasant, appropri- } \\
\text { ate to taste applied } \\
\text { additives, not suffi- } \\
\text { ciently pronounced, } \\
\text { without other tastes }\end{array}$ & $\begin{array}{l}\text { Weakly pro- } \\
\text { nounced taste of } \\
\text { the used additives }\end{array}$ & $\begin{array}{c}\text { Not expressed } \\
\text { taste }\end{array}$ & $\begin{array}{l}\text { Not in accordance, } \\
\text { extraneous taste of the } \\
\text { product, not character- } \\
\text { istic of the components } \\
\text { and additives that have } \\
\text { been applied }\end{array}$ \\
\hline smell & 0,2 & $\begin{array}{l}\text { Pleasant, corre- } \\
\text { sponding to this } \\
\text { type of product, } \\
\text { pronounced, no } \\
\text { smell }\end{array}$ & $\begin{array}{l}\text { Pleasant, corre- } \\
\text { sponding to this } \\
\text { type of product, } \\
\text { pronounced, with- } \\
\quad \text { out smells }\end{array}$ & $\begin{array}{l}\text { Slight smell of } \\
\text { used additives }\end{array}$ & $\begin{array}{l}\text { No pronounced } \\
\text { smell }\end{array}$ & $\begin{array}{l}\text { Not in accordance with } \\
\text { this type of product, } \\
\text { foreign smell, not char- } \\
\text { acteristic of additives } \\
\text { that have been applied }\end{array}$ \\
\hline
\end{tabular}

The developed point system allows organoleptic evaluation of new crispy breads of increased nutritional value, including them in one of the following categories: "excellent" (with a total rating of $4.5-5.0$ points), "good" (4.0-4.5 points), "satisfactory" (3.5-4.0 points) and "unsatisfactory" (below 3.5 points).

During the tasting, each taster was provided with samples of new crispy breads, the tasting list and scale were taken into account in rating, Table 1. Tasters possessed professional knowledge and sensory ability (sensitivity of smell, taste and memory), knew the properties of the product being assessed, production technology.

Statistical processing of organoleptic indicators was carried out as follows: first, the average points of evaluators of tasters for individual indicators. To do this, the summary table entered the estimates of all tasters for each sample and calculated the average arithmetic values of the estimates of individual indicators (in points) by the formula:

$$
\mathrm{x}=\frac{\sum_{\mathrm{i}=1}^{\mathrm{n}} \mathrm{x}_{\mathrm{i}}}{\mathrm{n}}
$$

where $\sum_{\mathrm{i}=1}^{\mathrm{n}} \mathrm{X}_{\mathrm{i}}$ - the sum of the tasters' evaluations for a specific indicator (appearance, color, etc.) of a single product sample, the score; $\mathrm{n}$ - the number of tasters.

To characterize the variation of the aggregate points of tasters determined the standard deviation for each single indicator by the formula:

$$
\mathrm{S}=\sqrt{\frac{\sum_{\mathrm{i}=1}^{\mathrm{n}} \mathrm{x}_{\mathrm{i}}^{2}}{\mathrm{n}}}-\overline{\mathrm{x}}^{2}
$$

where $\sum_{i=1}^{n} x_{i}^{2}-$ the sum of squares of tasters points, points; $\bar{x}^{2}-$ the square of the average value of the indicator scores, points.

The standard deviation S characterizes the consistency of expert opinions with homogeneity of samples, are analyzed. If $\mathrm{S}$ on a 5-point scale is no more than \pm 0.5 , the points are unambiguous; if the deviation is \pm 1 or more - evaluation is heterogeneous, which indicates a low training of tasters.

With the consistency of expert opinion, further calculation of the complex quality indicator Q (3) is carried out:

$$
\mathrm{Q}=\sum_{\mathrm{i}=1}^{\mathrm{n}} \mathrm{X}_{\mathrm{i}} \cdot \mathrm{K}
$$

where $\sum_{\mathrm{i}=1}^{\mathrm{n}} \mathrm{X}_{\mathrm{i}}$-the sum of the tasters' evaluation for a specific indicator (appearance, taste, etc.) of a single product sample, the score; $\mathrm{K}$ - weight coefficient. 
When determining the physico-chemical properties of crispy breads (mass fraction of moisture, bulk mass, impurities, infestation by pests of grain stocks and their larvae), standard research methods were used [11]. In accordance with these methods, spas are the standard laboratory equipment complex: electric drying cabinet (CEШ-3M), PE SumyKIPiA, Sumy, Ukraine (Fig. 1); desiccator (Pharmmedtech, Ukraine) (Fig. 2); electronic scales ScoutSC 2020 EU1, PA "Ukrspetskomplekt”, Ukraine (Fig. 3); liter grain tester ПX-1, SEP Pashkov V.A., Dnipro, Ukraine (Fig. 4); folding board, LLC Ukranalitika, Ukraine (Fig. 5); handheld magnifier, Ukraine (Fig. 6).

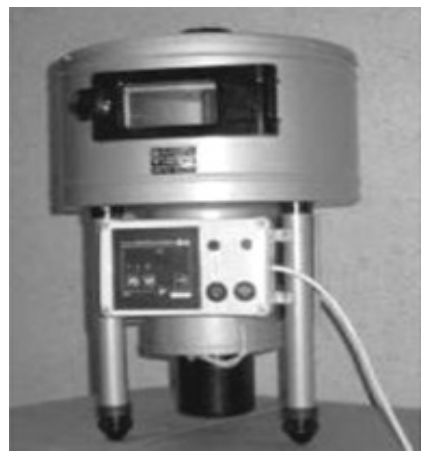

Fig. 1. Electric drying cabinet, СЕШ-3M

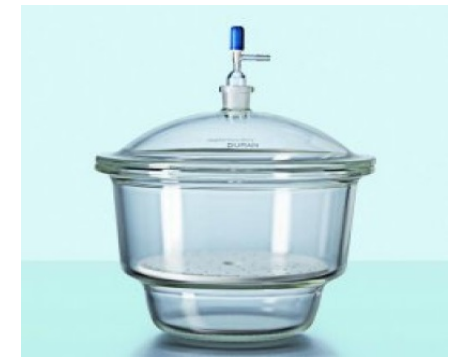

Fig. 2. Desiccator

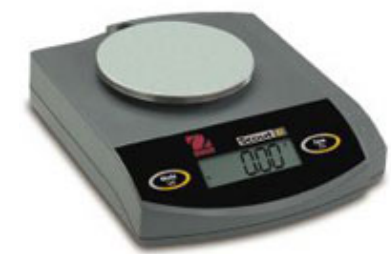

Fig. 3. Electronic scales ScoutSC 2020-EU1

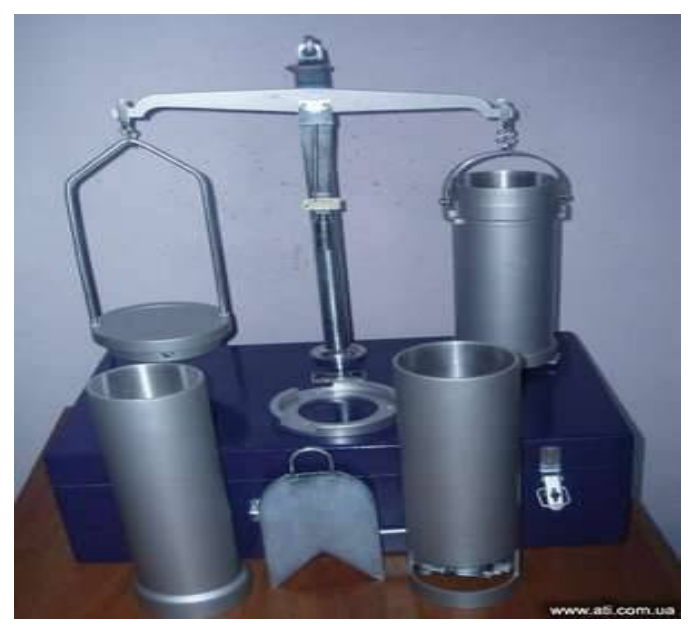

Fig. 4. Liter grain tester ПХ-1 


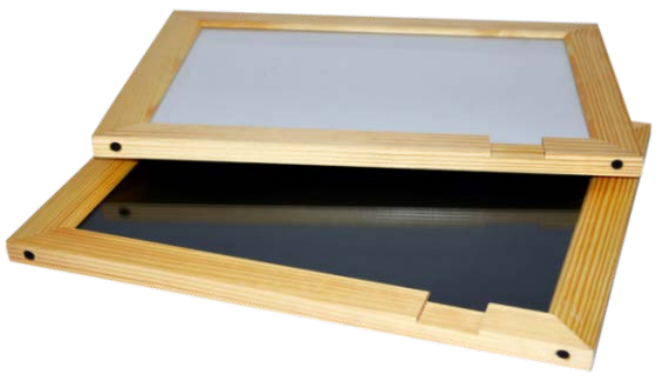

Fig. 5. Folding board

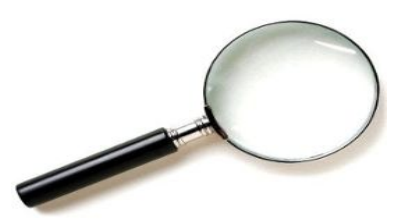

Fig. 6. Handheld magnifier

On the basis of the results of the calculation of the prescription composition in industrial conditions, control and prototypes of bread are produced: control - spelt-based bread sample 1 - spelt-based crispy breads with the inclusion of $5 \%$ of rosehip powder; sample 2 - spelt-based crispy breads with the inclusion of $5 \%$ mountain ash powder; sample 3 - spelt-based crispy breads with the inclusion of $5 \%$ milk thistle powder; sample 4 - spelt-based crispy breads with the inclusion of $5 \%$ green tea extract powder (Fig. 7).

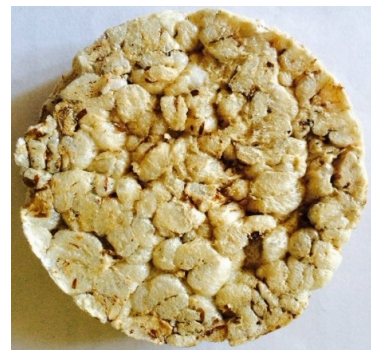

$a$

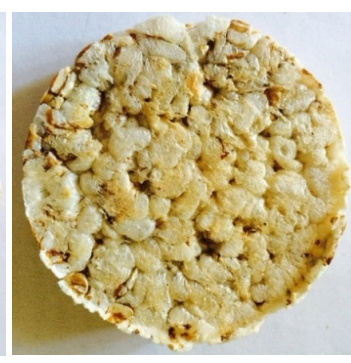

$b$

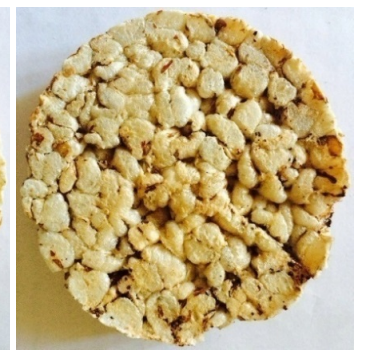

$c$

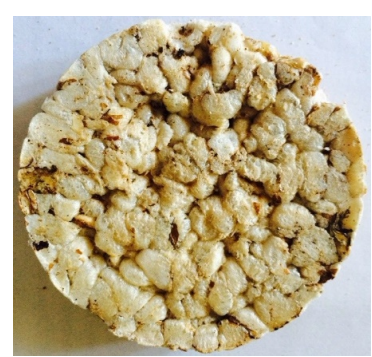

$d$

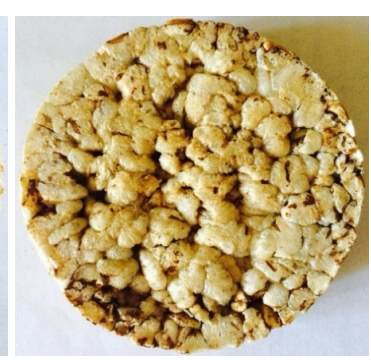

$e$

Fig. 7. Samples of crispy breads: $a$ - control; $b$ - sample 1 (with rosehip); $c$ - sample 2 (with mountain ash); $d$-sample 3 (with milk thistle); $e$ - sample 4 (with green tea extract)

\section{Results and discussion}

The tasting commission consisting of nine experts examining the crispy bread in accordance with the developed is taken into account in scale (Table 1). The commission is concluded that (Table 2), enriching the crispy bread with vegetable additives leads to an improvement in the consumer properties of finished products, namely, these products differed by attractive appearance, crispy structure, attractive light cream color, pleasant taste and pronounced smell of used additives. 
According to taste, crispy breads were distributed to the members of the tasting commission as follows:

1st place - "Bread with milk thistle", "Bread with rosehip" and "Bread with mountain ash", they were distinguished by a harmonious, pleasant taste, with an intense flavor of additives;

2nd place - "Bread with green tea extract" and "Control" was characterized by a pleasant, but not enough pronounced taste.

Table 2

Evaluation of organoleptic indicators of the quality of spelt-based bread samples, points

\begin{tabular}{|c|c|c|c|c|c|c|c|}
\hline \multirow{2}{*}{ Samples } & \multicolumn{5}{|c|}{ Name of indicators without weight ratio/weight ratio } & \multirow{2}{*}{$\begin{array}{c}\text { Overall } \\
\text { quality } \\
\text { evaluation }\end{array}$} & \multirow{2}{*}{$\begin{array}{c}\text { Quality } \\
\text { category }\end{array}$} \\
\hline & Appearance & Colour & Structure & Taste & Smell & & \\
\hline Control & $4,3 / 0,65$ & $3,5 / 0,53$ & $3,8 / 0,76$ & $4,1 / 1,23$ & $4,4 / 0,88$ & 4,05 & good \\
\hline Sample 1 & $4,9 / 0,74$ & $5,0 / 0,75$ & $4,9 / 0,98$ & $4,9 / 1,47$ & $4,7 / 0,94$ & 4,88 & excellent \\
\hline Sample 2 & $4,3 / 0,65$ & $4,9 / 0,74$ & $4,5 / 0,90$ & $4,7 / 1,41$ & $4,4 / 0,88$ & 4,56 & good \\
\hline Sample 3 & $4,9 / 0,74$ & $4,9 / 0,74$ & $4,9 / 0,98$ & $4,9 / 1,47$ & $4,9 / 0,98$ & 4,91 & excellent \\
\hline Sample 4 & $4,3 / 0,65$ & $4,4 / 0,66$ & $4,5 / 0,90$ & $4,4 / 1,32$ & $4,4 / 0,88$ & 4,40 & excellent \\
\hline
\end{tabular}

Thus, the introduction of vegetable additives in the composition of crispy breads to improve the organoleptic characteristics of finished products confirms the results of the tasting analysis. These products were characterized by a crispy, porous structure, an attractive light cream color, a harmonious taste, a pronounced smell of additives used. According to the results of the tasting evaluation, samples enriched with herbal supplements received the highest score in relation to the control sample, which meets the requirements of potential consumers.

Next to the organoleptic, physico-chemical indicators also characterize the complex properties that determine the quality of products. Physico-chemical indicators are regulated in the regulatory documentation for a specific type of product, they are due to the quantitative and qualitative composition of the initial components, which are determined by the constancy of the composition of the product. Changes in these indicators will lead to deterioration in quality and may cause the product to be useless.

Additives that are introduced into the product, should not lead to changes in the physico-chemical characteristics of the enriched product. In this regard, it is of interest to study the effect of herbal supplements on the physic-chemical indicators of finished products (Table 3).

Table 3

Physico-chemical properties of crispy bread samples

\begin{tabular}{cccccc}
\hline Indicators & Control & Sample 1 & Sample 2 & Sample 3 & Sample 4 \\
\hline Moisture content, \% & 8,1 & 8,4 & 8,4 & 8,4 & 8,5 \\
Bulk weight, g/dm & 548 & 619 & 614 & 623 & 611 \\
Impurities & & & & & \\
$\begin{array}{l}\text { Infection with pests } \\
\text { of grain stocks and } \\
\text { their larvae }\end{array}$ & & & not found &
\end{tabular}

Analysis of the experimental data shows that the replacement of a part of the grain starch-containing raw materials with a plant additive leads to a slight increase in indicators (mass fraction of moisture and bulk density) relative to the control. In our opinion, this is due to a significant decrease in the grain-based plant grain mixture by the biopolymer composition of the added 
additives. Impurities and pest infestation of grain stocks were not detected in any of the samples of crispy breads.

Thus, the introduction of the products of enrichment additives into the crispy breads does not impair the physic-chemical properties of these products.

\section{Conclusions}

On the basis of the organoleptic analysis, it has been established that the introduction of herbal supplements into the grain breads leads to an improvement in the organoleptic characteristics of the finished products, namely, the prepared breads are characterized by a crispy, porous structure, an attractive light cream color, a harmonious taste, a pronounced smell of the used additives. Introduction to the composition of crispy bread concentrators does not lead to a deterioration of the physico-chemical characteristics of these products.

Use when evaluation of the organoleptic indicators of the quality of developed crispy breads taken into account in scale allows to quickly characterize the quality of the food product. As a result, the results indicate the feasibility of producing new spelled-based grain breads with the inclusion of enriching herbal supplements (milk thistle, mountain ash, rosehip powder) with improved organoleptic properties. This will significantly expand the range of wellness products and significantly diversify the traditional nutrition of consumers seeking a healthy lifestyle.

Prospects for further research are: conducting a comprehensive merchandising assessment of new spelt-based crispy breads; determination of the optimal conditions and shelf life of new products; development of a set of marketing measures for the effective product distribution of the new product to the consumer market.

\section{References}

[1] Rogers, L. (2018). Sensory Panel Management. A Practical Handbook for Recruitment, Training and Performance. Woodhead Publishing, 376. doi: https://doi.org/10.1016/c2015-0-05914-7

[2] Rogers, L. (Ed.) (2017). Discrimination Testing in Sensory Science. A Practical Handbook. Woodhead Publishing, 518.

[3] Civille, G. V., Carr, B. T. (2015). Sensory Evaluation Techniques. CRC Press Taylor \& Francis Group, 600 .

[4] Saint-Denis, C. Y. (2018). Consumer and Sensory Evaluation Techniques: How to Sense Successful Products. John Wiley \& Sons Inc, 216. doi: https://doi.org/10.1002/9781119405559

[5] Mardar, M., Ustenko, I., Agunova, L., Znachek, R., Zhygunov, D. (2017). The Formation of Consumer Preferences to Functional Food Products. Scientific works of university of food technologies, 64 (1), 324-331.

[6] Kononenko, I. A., Docenko, V. A. (2012). Dieticheskaya ocenka produktov, izgotovlennyh s ispol'zovaniem termoplasticheskoy ekstruzii zernovogo syr'ya. Bezopasnost' zhiznedeyatel'nosti, 5, 10-14.

[7] Krasina, I. B., Danovich, N. K., Kaz'mina, O. I. (2015). Bezglyutenovye hlebcy s ispol'zovaniem netradicionnyh vidov syr'ya. Fundamental'nye issledovaniya, 2, 1626-1631.

[8] Shmalko, N. A., Klyndukhova, L. H., Klyndukhova, Yu. O. (2008). Tekhnolohichni osoblyvosti khrustkykh vyrobiv. Khlibopek, 1, 39-40.

[9] Mardar, M., Tkachenko, N., Znachek, R., Leonardi, C. (2017). Optimization of formulation composition of the crispbread with improved consumer properties. Technology Audit and Production Reserves, 2 (3(34)), 22-29. doi: https://doi.org/10.15587/2312-8372.2017.99941

[10] DSTU 2903:2005. Kontsentraty kharchovi. Snidanky sukhi. Zahalni tekhnichni umovy (2005). Derzhspozhyvstandart, 22.

[11] Yakovenko, A. I., Borta, A. V.; Stankevycha, H. M. (Ed.) (2015). Zberihannya zerna. Odessa, 95. 